удк 39(477.54.62)

Анатолій Кравченко

Сумський державний педагогічний

університет імені A. С. Макаренка

ORCID ID 0000-0002-9523-7435

DOI 10.24139/2312-5993/2019.07/355-366

\title{
ЗАСЕЛЕННЯ СЛОБІДСЬКОЇ УКРАЇНИ І РОЗВИТОК НАРОДНОЇ ОСВІТИ В СУМСЬКОМУ ПОВІТІ ТА СТАРОМУ СЕЛІ (1638-1917)
}

У статті висвітлено перебіг заселення Слобідської України мігрантами із середнього Подніпров'я. Наголошено на особливостях освітньої справи та посутній ролі земств у ії становленні. Із залученням історико-статистичних даних розглянуто стан народної освіти у Старому Селі. Констатовано, що Старе Село є найдавнішим поселенням на Сумщині, назва якого точно відображає його історію. Старе Село - че дворянське гніздо роду Кондратьєвих-Зборомирських, звідки почалась історія не лише м. Суми, а й усієї області. Проте, хоча Старе Село й було першим поселенням на цих теренах, воно не вело вперед в освітній справі. Лише завдяки сприянню сільської громади тут було відкрито народне училище. Подальші розвідки повинні бути спрямовані на більш глибоке дослідження народної освіти в Старому Селі

Ключові слова: Слобідська Україна, заселення, перше поселення, Старе Село, народна освіта, навчання, учень, учитель.

Постановка проблеми. Слобожанщина, або Слобідська Україна, - це історико-географічний район у межах нинішньої північно-східної частини України та південного сходу російського Чорнозем'я, що постав на перетині цих теренів, колишнього Дикого Поля і так званої Малоросії. Його назва походить від козацьких поселень, користувалися великими вольностями - слобід, мешканці яких були «слобожани» (тобто звільнені) від багатьох податків.

у XVI-XVII століттях на безлюдних територіях Дикого Поля все частіше почали з'являтися вихідці з Наддніпрянської України. Значний рух людності з українських земель, що перебували під владою Польщі, припадає на часи після поразки козацького повстання 1638 року на Лівобережній Україні. Саме тоді польський уряд ухвалив постанову «Ординація Війська Запорізького реєстрового, що перебуває на службі Речі Посполитої», спрямовану на ліквідацію козацьких привілеїв. Рятуючись від утисків польських поміщиків, податкового тягаря і прагнучи до збереження православної віри, переселенці вирушили на незаселені південні степові окраїни Московської держави.

Дослідники, припускаючи, що Слобідську Україну заселяли кілька хвиль переселенців із-за Дніпра, виокремлюють три головні переселення. Перше відбулося за царювання родоначальника династії Романових Михайла Федоровича в 1640-1645 роках у кількості 8000 осіб. Більшу 
частину цих переселенців становили вихідці із Задніпров'я. Друга, потужніша хвиля переселення в Слобідську Україну з Подніпрянщини припала на 1645-1647 роки, початок царювання Олексія Михайловича. Тоді переселилося 1247 родин, або дворів, і понад 2000 козаків. Третє переселення датовано 1650-1651 роками, і щодо нього відома тільки чисельність прибулих козаків - понад 500.

За переказами, перші переселенці та козаки під проводом осадчого Кондратьєва з'явились у Старому Селі, яке перебувало під захистом козацького форпосту, приблизно в 1638-1639 роках. Отже, історія Старосільського поселення нерозривно пов'язана з козаками із Центральної України, які поступово заселяли ці терени. Вивчаючи історію Старого Села, ми спиралися на працю видатного богослова, вченого, громадського діяча Дмитра Григоровича Гумілевського (Філарета) «Історико-статистичний опис Харківської єпархії» (Филарет (Гумилевский Д. Г.), 1857).

Села Старе і Низи знаходились одне на правому, інше на лівому, або лісовому, березі Псла. Перепис 1732 року свідчить, що Старе Село заселено «назад тому років 90», відтак у 1642 році, а отже, вік села відповідає його назві (Филарет (Гумилевский Д. Г.), 1857).

Це село є одним із найдавніших на Сумщині, оскільки виникло ще на самому початку освоєння теренів Слобідської України вихідцями 3 середнього Подніпров'я (Кравченко, 2018а, с. 183-185).

Хоча Старе Село є першим поселенням у Сумському полку, перші згадки про відкриття тут училища I (найнижчого) розряду ми знаходимо лише в доповіді Сумських чергових повітових земських зборів від 16-20 вересня 1886 року.

Аналіз актуальних досліджень. Аналіз доступних літературних джерел, архівних матеріалів та інтернет-ресурсів дав підстави зробити висновок про відсутність подібних розвідок. У ході дослідження було використано праці з історії України, матеріали Державного архіву Сумської області, журнали Сумських чергових повітових земських зборів, а також народні перекази мешканців Старого Села.

Мета статті - з'ясувати особливості становлення та розвитку народної освіти на теренах Слобідської України, Сумського повіту, у Старому Селі.

Методи дослідження: теоретичні - аналіз спеціальної літератури та історичних документів із зазначеної проблеми.

Виклад основного матеріалу. Земські училища - це загальноосвітні початкові школи з одно-, три- та чотирирічним курсом навчання, які відкривалися й утримувалися земствами в сільській місцевості та діяли на підставі «Положення про губернські та повітові земські установи» 1864 року, що обмежувало освітню діяльність земств розв'язанням фінансово-господарських питань. Нагляд за земськими училищами та 
педагогічне керівництво ними здійснювали члени училищних рад, контроль - інспектори та директори народних училищ міністерства освіти.

У земських училищах викладали Закон Божий, читання, письмо, церковнослов'янську мову, арифметику, співи. Оскільки для цього типу шкіл не існувало сталих програм, учителі могли обирати доцільні методи навчання й відповідні підручники, збільшувати обсяг початкових знань, викладаючи природознавство, фізику, хімію, географію та історію. До земських училищ ішли працювати випускники прогімназій, гімназій, учительських і духовних семінарій, єпархіальних училищ і приватних закладів освіти. Як правило, переважна більшість педагогів навчала за книгами Т.Г. Шевченка, К. Д. Ушинського, П.О.Куліша, Л. М. Толстого, М. О. Корфа. При багатьох училищах діяли народні бібліотеки, недільні читання, класи для дорослих, учнівські хори, ремісничі майстерні та класи, проводилися заняття з городництва, садівництва і бджільництва. 3-поміж усіх початкових шкіл найкращими були земські, де вчителі використовували більш прогресивні методи навчання, а його зміст був дещо ширшим і включав відомості з географії, історії, природознавства.

У 1837 році в Східній Україні діяло 17 тисяч початкових шкіл, проте вони охоплювали лише третину дітей. Не всі діти селян і робітників відвідували школи через скрутне матеріальне становище родин, тому рівень грамотності простолюду, особливо селян, був низьким. За даними перепису 1897 року, $76 \%$ населення Російської імперії залишалося неписьменним. Одночасно, вже за даними 1913 року, 73 \% призовників уже були грамотними, а в 1916 році цей показник сягнув 80\%, хоча в багатьох європейських країнах грамотність тоді була вищою.

Наприкінці XIX століття, порівняно з його серединою, початкових шкіл в Україні стало у 12 разів більше, але потреби народу в початковій освіті вони не задовольняли. На той час у різних губерніях України рівень елементарної грамотності коливався в межах 15-20 \%. Початкова освіта для простолюду була відсталою, натомість діти із заможних родин отримували покращену початкову освіту в спеціальних підготовчих класах гімназій або вдома. На початку XX століття 84 \% коштів на утримання шкіл виділяли земства, 14 \% - міністерство освіти, 2 \% - духовне відомство.

Маємо зазначити, що якість навчання в народних школах була низькою. Особливо примітивну освіту давали церковно-парафіяльні, які на 1900 рік становили $80 \%$ усіх початкових шкіл та існували на пожертви парафіян. Навчання тут обмежувалося читанням слов'янською і російською мовами, азами арифметики та вивченням молитов.

На початку XX століття в Російській імперії та на теренах підросійської України склалася доволі строката й заплутана система народної освіти, що характеризувалася неузгодженістю навчальних планів початкової та середньої ланок. Існувало понад 20 типів шкіл (державні та приватні, 
платні та безкоштовні, конфесійні та світські, чоловічі та жіночі), але право вступити до університету давали лише чоловічі класичні гімназії, а решта середніх шкіл (реальні, комерційні училища, кадетські корпуси) відкривали випускникам шляхи до вищих технічних, сільськогосподарських, економічних тощо закладів освіти.

Обмеженістю відзначалася середня і вища освіта для жіноцтва. Рівень освіти в усіх жіночих середніх закладах (гімназіях, єпархіальних училищах, інститутах шляхетних дівчат) був набагато нижчим, ніж у чоловічих. Жінки практично не мали змоги вступити до університетів і вищих технічних шкіл, натомість для них організовувалися Вищі жіночі курси.

Таким чином, до 1917 року на теренах Лівобережної України діяли такі заклади освіти: військові (академії, училища, юнкерські училища, кадетські корпуси, прогімназії тощо), волосні училища, недільні школи, вищі початкові училища, вищі жіночі курси, гімназії, православні духовні академії, духовні семінарії, духовні та початкові училища (земські школи), інститути, інститути шляхетних дівчат, комерційні, народні та реальні училища, реальні гімназії, університети, вчительські семінарії та школи, церковно-парафіяльні школи.

Відомості про освіту в Старому Селі періоду земства містять журнали Сумських чергових повітових земських зборів. Збереглися звіти кінця XIX - початку XX століття, які засвідчують, що на той час у селі діяло земське однокласне народне училище, що належало до I розряду. Працювали також народна бібліотека-читальня і недільна школа.

У журналі чергових земських зборів від 1886 року вміщено доповідь земської управи від 29 червня про відкриття такого училища. У ній ідеться про клопотання старосільської громади щодо відкриття училища I розряду. Допомогу громаді в цій справі надав землевласник Лев Михайлович Зборомирський.

У журналі Сумських чергових повітових земських зборів за 1888 рік подано доповідь про відкриття в Старому Селі училища.

Викладання в училищах здійснювалося на підставі чинного на той час документа «Орієнтовні програми предметів, що викладаються в однокласних і двохкласних народних училищах відомства Міністерства Народної Просвіти». Програма включала такі предмети: «Закон Божий», «Читання за книгами і церковного друку», «Письмо», «Арифметика», «Співи». Особлива увага приділялася вивченню Закону Божого, що зі схвалення Святійшого Синоду тривало впродовж 3 років: перший рік вивчення молитви зі слів законовчителя та пояснення її необхідності; другий рік - повторення молитов і вивчення важливих подій зі Старого і Нового Заповіту; третій рік - пояснення Символу Віри, заповідей, богослужіння, повторення вивченого. Заняття починали з читання або проспівування повсякденної молитви. 


\section{Сумскому очередному зеискому собранію}

\section{СУМСКОЙ ЗЕМСКОЙ УІРАВЫ \\ Д0 К Л А Дъ}

объ открытіи въ сөль Старомъ училища.

На разсмотръвіе очереднаго земскаго собранія сессіи 1886 года земская управа вносила ходатайство. 1 и 2 Старосельских'ь сельскихъ обществъ объ открытіи въ с. Старонь училища I разряда на сльддующихъ условіяхъ: иьстный землевладыллецъ Левъ Михайловичъ Зборомірскій пожертвоваль крестьянащт зданіе для училища, а крестьяне обязались, на собственный счетъ, перенести это зданіе на другое мь九сто, обстроить его и приспособить его для училищныхъ пьлей; когда же зданіе будеть окончено и принято управою, крестьяне обязались ежегодно вносить на содержаніе его по 180 руб., т. е. такую сумиу, какая именно и требуется оть сельскихь обтествь на содержаніе училища I разряда. Но такъ как'ь въ первоначальномъ общественномъ приговорь оть 29 іюня 1886 года не заключалось обязательства сельскихъ обществъ и объ отводы и передачь⿱宀 училищу общественной зеили, то управа, высказавшись за удовлетвореніе вышеприведеннаго ходатайства, находила, однако, необходимымъ, во избъжаніе қакихъ- 
либо недоразумънній въ будущемъ, потребовать отъ Старосельскихъ обществь, чтобы они обязались отвести усадебное мъстто подь училище, которое и должно считаться училищнымъ, а не общественнымъ. Съ этимъ мнъніемъ управы земское собраніе согласилось и, принявъ докладъ ея въ засьданіи 18 сентября 1886 года; открыло управъ кредить изъ земскихъ сборовъ въ сумй, какая потребуется на содержаніе училища въ с. Старомъ въ 1887 году, если сельскими обществами будуть выполнены всь принятыя ими на себя обязательства.

Хотя Старосельскія общества еще 25 января прошлаго 1887 года составили и. представили въ земскую управу требуемый приговорь объ отводъ подъ училище около 300 квад. саж. общественной земли, но къ постройкъ училищнаго зданія по плану, рекомендованному земской управой, приступили и окончили ее только въ текущемъ году, всльдствіе того, что въ зданіи, пожертвованномъ крестьянамъ землевладььльдемъ Л. М. Зборомірскимъ, оказалось много негоднаго матеріала, и общества только въ этомъ году собрались со средствами на покупку всего необходимаго для постройки.

На устройство зданія для училища, съ добавленіемъ необходимыхъ матеріаловъ, сарайчика для дровъ и огорожу училища крестьянами израсходовано, по донесенію сельскихъ старость 1 и 2 Старосельскихъ обществъ, 1,153 руб. 43 коп.

ПІочти на всю эту сумму сельскіе старосты представили въ управу оправдательные документы, въ видъ счетовъ изъ разныхъ магазинов' и росписокъ в' платежь денегь за работы и матеріалы, и просять возвра- 
тить крестьянскимъ обществащъ половинную часть затраченной ими суммы.

Покладывая 0 вышеизложенномь, земская управа имъеть честь заявить собранію, что зданіе училища вь с. Старомъ осмотрћно ею чрезъ одного изь свопхъ членовъ и прдзнано устроеннымъ удовлетворительно; въ длину оно имбеть 19 и въ ширину 10 арш., крыто жельвзомь, оштукатурено глиной п помьшаеть въ себю: 2 сьней, корридорь для разджванья јчениковь, 2 классныхъ комнаты, комнату для библіотеки, 2 комнаты для квартиры учителя и чулань; при училищь јстроенъ плетневый сарайчикъ, для храненія топлива, крытый соломой и обмазанный глиной, устраивается отхожее мьнсто и усадьба съ двухъ сторонъ обносится птакеTOMъ.

Такь какь крестьяне с. Стараго не возбудили ранеье ходатайства о принятіи на счеть земства половинной части расходовъ на устройство зданія, то всь работы пропзводились безъ наблюденіа и контроля земской управы, а потому пьнность работь и матеріаловъ управой съ точностью опредьлена быть не можеть; но, въ виду оправдательныхъ докјментовъ, представленныхъ С'таросельскими старостами на сумму 1,095 руб. 5 коп. и въ виду общаго вполнь удовлетворительнаго вида училища, земская управа ничего не можеть возразить противь показанной стоимости работь и, принявъ во вниманіе, что при устройствћ училищныхъ зданій въ селахъ Сјмскаго увзда, вездь' участвовало земство въ половиной части, ходатайствуеть предъ земскимь собраніемь о принятіи на счетьь земства половинной части расходовъ, 
пропзведенныхъ и при постройкь јчилища въ с. Старомъ, въ сјммь 576 руб. $71_{i 2}^{1 /}$ коп.; ассигновавъ также; по примьру прочихъ училищ' I разряда, 262 руб. 50 коп. на его содержаніе сь наступивмаго учебнаго года. Подлинный подписали: Предсьватель управы Де-Конноръ, члены: К. Линтваревъ, Н. Ефрремовъ и Д. Величко.

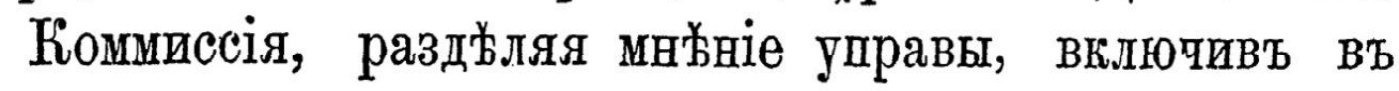
общую смёту на содержаніе училища 262 р. 50 коп., потребныхъ на содержаніе Старосельскаго училища, просить внести въ смь̈ту особой статьею 576 р. $71^{1 / 2}$ коп. на возврать обществу за постройку училища. Подлинное подписали: Предсьвдатель ревизіонной коммиссік И. Траскинъ, ч.лены: А. Рпхтеръ.

Грамоти навчали з використанням звукового способу. Сутність цієї методики полягала в тому, що вчитель повинен був дати певні відомості та прийоми, за допомогою яких легше розпочати навчання грамоті та письму. На вивчення абетки відводилося 6 тижнів, далі тривало читання за букварем. «Упородовж трирічного курсу прагнули навчитися читати швидко й усвідомлено, переказати прочитане за запитаннями, а потім самостійно. Вправлятись у вивченні байок та віршів».

У звіті зазначено, що чисельність тих, хто бажає навчатися, перевищує кількість вакантних місць, учні сумлінно відвідують уроки й рідко їх пропускають. Лише діти, які мешкали поблизу цукрових заводів і плантацій, приходили до школи після закінчення сезонних робіт, оскільки могли заробити 20-30 коп. Утримання одного учня коштувало 8 руб. на рік. Час занять скорочувався Великим Постом, «упродовж якого на різних тижнях школи говіли, а отже, майже не вчились, а згодом святом Великодня». Через тиждень після нього складалися іспити.

Крім своїх прямих обов'язків, більшість учителів мали й інші. Вони спільно з учнями за додаткову платню займалися садівництвом i рукоділлям, завідували бібліотеками-читальнями, організовували недільні читання, працювали в недільних школах.

Коли траплялись епідемії (кір, скарлатина, дифтерія), школи зачинялися на карантин, що тривав два тижні та більше. 

виділялося:

На утримання одного народного училища I розряду на рік

«на платню учителеві - 300 руб.,

на платню законоучителеві - 60 руб.,

на платню сторожеві - 40 руб.,

на опалення - 30 руб.,

на освітлення - 5 руб.,

Усього: 435 руб.»

Ці кошти надходили з двох джерел: 255 руб. від Сумського земства і 180 руб. від сільської громади.

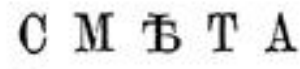

Сумской уьздной земской управы на содержаніе земскихт народныхъ училищъ въ $188^{8} / 9$ учебномь году.

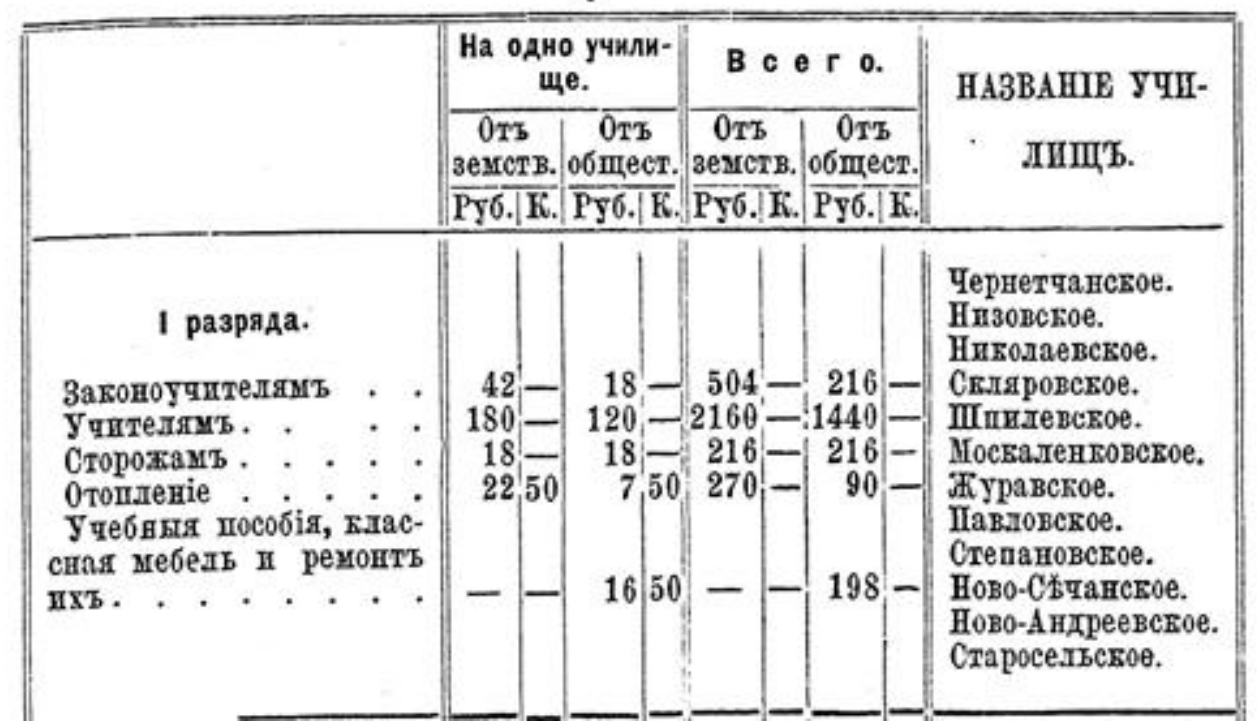

Кошторис утримання земських народних училищ у 1888-1889 н.р.

Кожне училище мало свого опікуна. У журналі Сумських чергових повітових земських зборів, які відбулися 13-17 вересня 1898 року, четвертим пунктом (с. 26) було вміщено доповідь інспектора народних училищ про стан народної освіти. Збори ухвалили висловити подяку опікунам, у тому числі й опікунові училища I розряду Старого Села Є.Ф.Зборомирській, за підтримку народних училищ. На цих зборах (с. 27) також було обговорено питання про нагородження вчителів народних училищ Сумського повіту, зокрема й учительки Юлії Біляєвої (Старе Село).

Опікуни щороку організовували для учнів різдвяні ялинки, виділяли кошти на поточні потреби. Так, Є. Ф. Зборомирська у 1898 році виділила Старосільському училищу 10 руб. і 2 сажні дров, а в 1900 році - книг на 15 руб. 
Наприкінці 1898 р. в Сумському повіті відсоток дітей, які навчались у земських народних училищах становив 52,62 \%, з них 88 \% - мешкали в селах (Кравченко, 20186, с. 131-148).

На чергових повітових земських зборах, які відбулися 21-24 вересня 1900 року, було заслухано доповідь управи про асигнування на утримання знову відкритих недільних шкіл у селах Нижня Сироватка, Біловоди, Старому тощо (пункт 12). Крім цього, 16-м пунктом було розглянуто доповідь про матеріальне заохочення вчителів земських початкових училищ, зокрема Старосільського, - вчительці Юлії Біляєвій було виділено 50 руб.

Стан народної освіти за 1901 рік було висвітлено в журналі чергових повітових земських зборів за 1-5 жовтня 1902 року інспектором народних училищ. У звіті зазначено, що в 1901 році кількість сільських шкіл, підпорядкованих міністерству народної освіти, становила 47 (Старосільська йде під номером 36), крім того, було відкрито й недільні школи (19-а функціонувала в Старому Селі). На с. 165 журналу за 1902 рік наголошено, що необхідно звести нові будівлі для 4 шкіл: Кровнянської, Старосільської, Климівської та Вирівської. На с. 169 згадано про бібліотеки-читальні в 40 населених пунктах, у тому числі й у Старому Селі.

Висновки та перспективи подальших досліджень. Виходячи 3 вищезазначеного, можна констатувати, що Старе Село $є$ найдавнішим поселенням на Сумщині, назва якого точно відображає його історію. Старе Село - це дворянське гніздо роду Кондратьєвих-Зборомирських, звідки почалась історія не лише м. Суми, а й усієї області. Проте, хоча Старе Село і було першим поселенням, на цих теренах, воно не вело вперед в освітній справі. Лише завдяки сприянню сільської громади тут було відкрито народне училище. Подальші розвідки повинні бути спрямовані на більш глибоке дослідження народної освіти в Старому Селі.

\section{ЛІТЕРАТУРА}

Филарет (Гумилевский Д. Г.) (1857). Историко-статистическое описание Харьковской епархии: из 5 отделений. Энциклопедия истории Слободской Украины. Режим доступа: http://dalizovut.narod.ru/filaret/filar_s.htm (Filaret (Gumilevskii, D. G.) (1857). Historical and statistical description of the Kharkov diocese: from 5 branches. Encyclopedia of the history of Sloboda Ukraine. Retrieved from: http://dalizovut.narod.ru/filaret/filar_s.htm).

Кравченко, А. І. (2018а). Стислий екскурс в історію Старосільського поселення. Старе Село та околиці першого поселення Герасима Кондратьєва (історія, сучасність, 1642 - 2018 рр.). Суми (Kravchenko, A. І. (2018a). A brief excursion into the history of the Starosilskyi settlement. The Old Village (Stare Selo) and the outskirts of the first settlement of Gerasym Kondratiev (history, modernity, 1642-2018). Sumy).

Кравченко, А. І. (2019). Народна освіта в С. Старому - першому поселенні Герасима Кондратьєва, Сумському повіті та Слобідській Україні у складі царської Росії в XVI - XX ст. Герасим Кондратьєв. Історія Старого Села, Сумського району (повіту). Суми: 
[ФОП Цьома С. П.], 210-228 (Kravchenko, А. I. (2019). National education in the Old Village (Selo Stare) - the first settlement of Gerasym Kondratiev, Sumy county and Slobidska Ukraine as part of tsarist Russia in the XVI - XX centuries. Herasym Kondratiev. History of the Old Village (Stare Selo), Sumy district (county). Sumy: [Tsioma S. P.], 210-228).

Кравченко, А. І. (2018б). Загальна характеристика народної освіти в Сумському повіті та будівництво і відкритт, училища першого розряду в селі Старому - першому поселенні Герасима Кондратьєва (1886 - 1888 р). Педагогічні науки: теорія, історія, інноваційні технології, 1 (75), 46-54 (Kravchenko, A. I. (2018b). General characteristics of education in Sumy district and the construction and opening of the school of the first level in the Old village - the first settlement of Gerasym Kondratiev (1886-1888). Pedagogical sciences: theory, history, innovative technologies, 1 (75), 46-54).

\section{PEЗЮME}

Кравченко Анатолий. Заселение Слободской Украины и развитие народного образования в Сумском уезде и Старом Селе (1638-1917).

В статье рассмотрен ход заселения Слободской Украины мигрантами из среднего Поднепровья. Подчеркнуты особенности образовательного дела и важная роль земств в его становлении. С привлечением историко-статистических данных рассмотрено состояние народного образования в Старом Селе. Констатировано, что Старое Село является древнейшим поселением на Сумщине, название которого точно отражает его историю. Старое Село - это дворянское гнездо рода Кондратьевыхзборомирских, откуда началась история не только г. Сумы, но и всей области. Однако, хотя Старое Село и было первым поселением, на этих территориях, оно не вело вперед в образовательной работе. Только благодаря содействию сельской общины здесь было открыто народное училище. Дальнейшие разведки должны быть направлены на более глубокое исследование народного образования в Старом Селе.

Ключевые слова: Слободская Украина, заселение, первое поселение, Cтарое Село, народное образование, обучение, ученик, учитель.

\section{SUMMARY}

Kravchenko Anatolii. Settlement of Sloboda Ukraine and development of public education in Sumy County and the Old Village (1638-1917).

The article discusses the process of settlement of Sloboda Ukraine by migrants from the middle Dnieper region. It is suggested that there were three waves of migrants from the Dnieper region, identifying three major displacements. The first occurred during the reign of the ancestor of the Romanov dynasty, M ykhailo Fedorovych, in 1640-1645 in the number of 8000 people. Most of these displaced persons were from the Dnieper region. The second, more powerful wave of resettlement in Sloboda Ukraine from the Dnieper region occurred in 1645-1647, the beginning of the reign of Oleksii M ykhailovych. Then moved 1247 families, or yards, and more than 2000 Cossacks. The third relocation dates to 1650-1651, and only the number of Cossacks who arrived there is known to be more than 500 .

The features of educational affairs and the important role of Zemstvos in its formation are emphasized. It is noted that Zemstvo schools are general secondary schools with one-, three- and four-year courses of study, opened and maintained by Zemstvos in rural areas and operated on the basis of the "Provinces on Provincial and County Zemstvo Institutions" in 1864, which limited the educational activities of Zemstvos by solution of financial and economic issues. Supervision and pedagogical management of Zemstvo schools was carried out by members of school councils, control - by inspectors and directors of public schools of the Ministry of Education. 
Using historical and statistical data, the state of public education in the Old Village (Stare Selo) is considered. It is stated that the Old Village is the oldest settlement in Sumy region, the name of which accurately reflects its history. The Old Village is a noble nest of the Kondratiev-Zboromyrskyi family, from where the history of not only the city of Sumy, but the whole region began. However, although the Old Village was the first settlement in these territories, it did not lead forward in educational work. It was only thanks to the assistance of the rural community that a public school was opened here.

Further studies should be aimed at a deeper analysis of public education in the Old Village.

Key words Sloboda Ukraine, settlement, first settlement, Old Village, public education, education, student, teacher.

$$
\text { удк 37.02:378.4(477-81) }
$$

Оксана Нефедченко

Сумський державний педагогічний університет імені А. С. Макаренка ORCID ID0000-0003-1656-2422

DOI 10.24139/2312-5993/2019.07/366-380

\section{СТАНОВЛЕННЯ ТЕХНОЛОГІЙ ЕВРИСТИЧНОЇ ОСВІТИ В УКРАЇНСЬКІЙ ВИЩІЙ ПЕДАГОГІЧНІЙ ШКОЛІ}

У статті здійснено аналіз розвитку основних ідей і технологій евристичної освіти у вітчизняній педагогіці. На основі історико-генетичного та історикопорівняльного аналізу виокремлено основні етапи становлення й розвитку евристичної освіти з їі технологіями евристичного навчання в українських закладах вищої освіти (ЗВО), зокрема в педагогічних університетах, протягом XXXI століття. Узагальнено тенденції розвитку інноваційних технологій евристичної освітньої системи зі ствердженням пріоритетів пізнавально-творчої і профресійнотворчої діяльності, спрямованої на підготовку креативної особистості майстерного, гуманістично спрямованого педагога.

Ключові слова: технології евристичної освіти, вітчизняна педагогіка, заклади вищої освіти (ЗВО), пізнавально-творча і профресійно-творча діяльність, креативний, гуманістично спрямований педагог.

Постановка проблеми. Україна як самостійна, демократична держава переживає еру модернізації, великих змін, які супроводжуються суттєвими реформами в кожній життєвій сфері - економіці, медицині, інженерії, у сфері ІТ-технологій, агрономії тощо. Безумовно, освіта як надійний фундамент становлення та розвитку громадянина високорозвиненої країни має займати ключове місце в суспільстві, створювати нову, творчо-гуманістичну освітню систему замість застарілої, авторитарної, переважно монологічної системи навчання й виховання підростаючого покоління. Але хто буде навчати таку молодь творчо та критично мислити, знаходити нестандартні підходи в розв'язанні складних ситуацій і проблем? Лише сучасний педагог, звільнений від шаблонів мислення та страху сказати «щось не те», здатний виховувати самодостатню, творчу особистість 3 іï постійним прагненням до 